\title{
An attempt to prepare local Guidelines for Management of Syndrome of Inappropriate ADH Secretion (SIADH) in a District General Hospital in the UK \\ Avraneel Talapatra ${ }^{1}$, Ian O'Connell ${ }^{2}$ and Indrajit Talapatra ${ }^{2}$

1. Manchester Medical School, UK, 2. Royal Albert Edward Infirmary Wigan, UK

\section{OBJECTIVE}

To establish the Guidelines for management of SIADH in a District General Hospital in the UK

\section{METHODS}

The European 2014 and NIH Guidelines are considered. The essential criteria for diagnosis of SIADH are taken into account.

\section{DIAGNOSIS}

Diagnostic Criteria:

1. Plasma Sodium $<130 \mathrm{mmol} / \mathrm{l}$

2. Plasma Osmolality $<275 \mathrm{mOsm} / \mathrm{kg}$

3. Urine Osmolality $>100 \mathrm{mOsm} / \mathrm{kg}$

4. Urine Sodium $>30 \mathrm{mmol} / \mathrm{l}$

5. Patient Clinically Euvolaemic

6. Exclusion of Glucocorticoid deficiency

7. Normal Thyroid function

8. Normal Renal function

9. On no diuretics

\section{THERAPY OF SIADH BASED ON} SEVERITY OF SYMPTOMS adapted from [1]

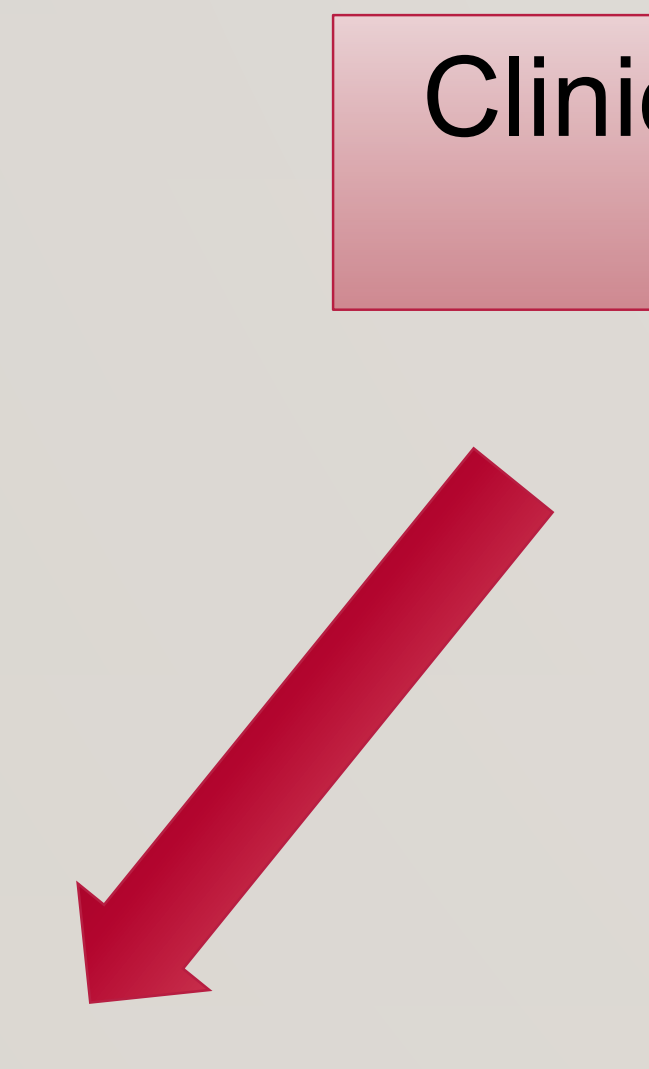

Grave symptoms

(fits, hemiplegia, severe

somnolence,

respiratory

insufficiency)

$3 \%$ saline symptoms

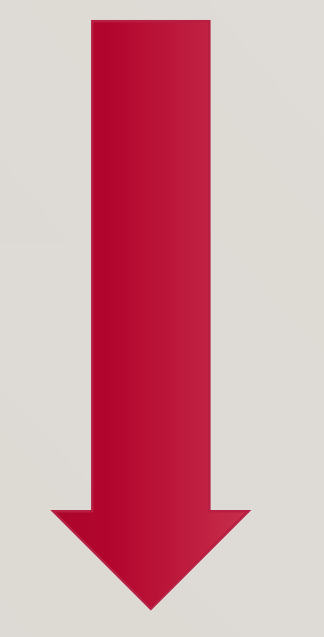

Advanced symptoms

(confusion,

vomiting, drowsiness, hallucinations) $\downarrow$

Vaptan, $3 \%$ saline
Clinical importance of signs and

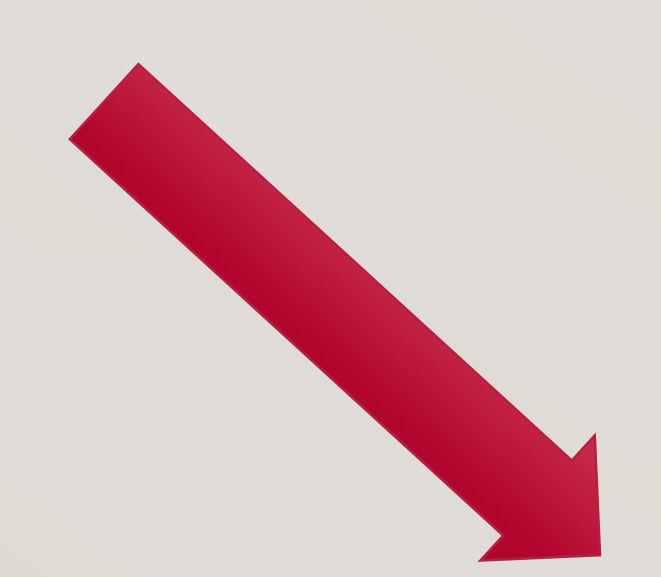

Mild to Moderate symptoms

(poor

concentration, nausea, instability of gait and falls)

Vaptan, urea, fluid restriction, demeclocycline

\section{PROPOSED GUIDELINE: MANAGEMENT OF DIAGNOSED SIADH}

Restrict Fluid intake to $500-1000 \mathrm{ml}$ daily Investigate and treat the cause (CXR, CT men and Pelvis, CT Head,

Demeclocycline (600 to $1200 \mathrm{mg} / \mathrm{d}$ ) if kidney function
kilable with mon

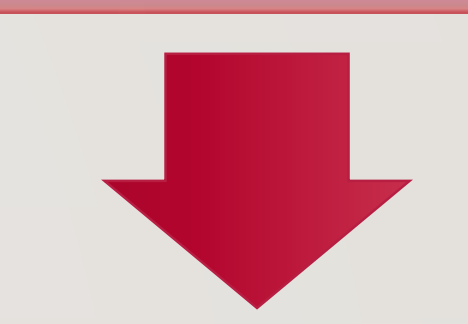

Tolvaptan from $7.5 \mathrm{mg}$ to $15 \mathrm{mg}$ daily. Measure plasma sodium at 6,12 and 24 hours. Patient allowed free fluids. Monitor LFTs and stop it if patient develops features of hepatic impairment.

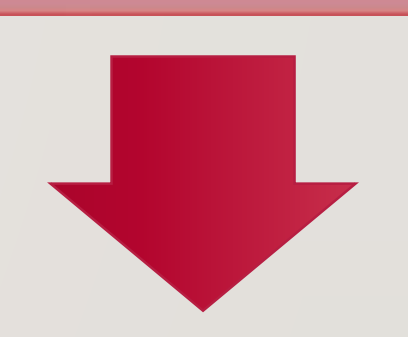

Aim to increase plasma sodium by 10 $\mathrm{mmol} / \mathrm{l}$ over 24 hours and $18 \mathrm{mmol} / \mathrm{l}$ over 48 hours

If the patient is acutely symptomatic and lasma sodium is not improving, refer to ITU for $3 \%$ hypertonic saline $+/-$ loop. diuretics

Management on ITU [2]

- First-hour management, Acute (<48h) and Chronic: Prompt IV. infusion of $150 \mathrm{ml} 3 \%$ hypertonic saline over $20 \mathrm{~min}$. Check the serum sodium concentration after $20 \mathrm{mins}$ and repeat an infusion of $150 \mathrm{ml} 3 \%$ hypertonic saline for the next $20 \mathrm{~min}$.

- If symptoms resolve after a rise of serum sodium of $5 \mathrm{mmol} / \mathrm{l}$, keep the IV line open with normal saline.

- $\quad$ Limit the increase in serum sodium concentration to a total of $10 \mathrm{mmol} / \mathrm{l}$ during the first $24 \mathrm{~h}$ and an additional $8 \mathrm{mmol} / \mathrm{l}$ during every $24 \mathrm{~h}$ thereafter until the serum sodium concentration reaches $130 \mathrm{mmol} / \mathrm{l}$.

- However, if symptoms do not improve after a rise in serum sodium of $5 \mathrm{mmol} / \mathrm{l}$ in 1 hour to continue an IV infusion of $3 \%$ hypertonic saline aiming for an additional $1 \mathrm{mmol} / \mathrm{l} \mathrm{per} \mathrm{h}$ increase in serum sodium concentration (using Adrogue-Madias formula).

- To stop the infusion of $3 \%$ hypertonic saline when the symptoms improve, the serum sodium concentration increases $10 \mathrm{mmol} / \mathrm{l}$ in total or the serum sodium concentration reaches $130 \mathrm{mmol} / \mathrm{l}$, whichever occurs first.

In the UK $2.7 \%$ hypertonic saline is available and can also be used instead of $3 \%$ saline

\section{CONCLUSION}

To limit the rise of plasma sodium to $10-12 \mathrm{mmol} / /$ over first 24 hours. In refractory cases referral may be done for haemodialysis, CVVH (Continuous Veno veno haemofiltration) and SLEDD.(Slow Low Efficiency Daily Dialysis)

913-EP

\section{REFERENCES}

